Eugeniusz Budny

Institute of Mechanised Construction and Rock Mining

Jan Szlagowski

Warsaw University of Technology, Institute of Heavy Machinery Engineering

Wiesław Trąmpczyński

Kielce University of Technology

\title{
AUTOMATION OF CONSTRUCTION MACHINERY OPERATION - INVESTIGATIONS IN POLAND
}

\begin{abstract}
The paper reviews some investigations carried in Poland in the field of construction machinery (excavators, jib cranes, overhead cranes etc.) working process automation. The following subjects are presented: operating movement control, dynamic modeling, construction of control algorithms, communication operator machinery. At the end, the two examples of practical applications are discussed. The comprehensive reference list of dissertation published by the Polish authors is included.
\end{abstract}

Key words: Building machinery, modeling, simulation, automation, fuzzy logic.

\section{Introduction}

This article presents the investigations conducted in Poland on methodology of automation of heavy machinery operation. Because of operation environment and process variation, the construction machinery is a difficult object for automation. However, automation of working processes is one of the main development tendencies for heavy machinery. In spite of the fact that presentation of the automated excavator FUTURE by Orenstein \& Koppel in 1983 was an event, first of all it was an exhibition happening. Nowadays almost every manufacturer says in his promotion materials that his product already is or will be equipped with elements of automatics.

Studying the process of automation of heavy machinery operation, the two distinct tendencies can be pointed out. The first one is continuous design modernization, without significant changes in machine shape, yet raising up its technical level. And the second one is deeply advanced actions for substantially reduction of human's role in decision process for choosing the best operational parameters of working system. Both tendencies are complementary and may be an essential part of further technological progress.

Systematizing the construction machinery development so far, we can assume that it was oriented on:

- saving energy,

- increasing work efficiency,

- improving work precision,

- improving human comfort and safety,

- environment protection.
Further step in automation deserves intervention in machine operating movements, however this requires deep knowledge of cutting process and complicated control algorithms. The following problem arises: on which stage operator management should be replaced and to which level the controller correction of working equipment movements imposed by the operator can be allowed?

Automation of machine working process especially should concern these functions, for which the operator makes mistakes because of not being able to select the proper parameters. This could result from lack of experience or lack of possibility to monitor the process. On the second stage the functions which operator realizes in cycles with the same parameters can be automated. The stress should be put on joining these movements to speed up the machine working process cycle.

In Poland the investigations concerning this subject are carried out since 1986, under government research projects and Scientific Research Committee grants. The results of these investigations are presented in this paper. They relate to the methodology of creating machine functional models, on-board digital control and management systems, advanced methods of dynamic modeling of machines, operator constructional machinery systems. And finally, examples of practical applications are provided.

\section{Positioning of working equipment \\ The problem of machine operating} movements is considered by several scientific centers in our country. The approach to this matter 
is based on various optimization criteria. Research trends could be split into the two main directions:

- the first one based on tool guidance kinematics optimization,

- and the second one based on cutting process optimization.

While the first way is already blazed by robotics, the cutting process optimization is a completely innovative solution. Nevertheless in both approaches it is assumed that machine operation optimization should particularly refer to these functions, for which the operator makes mistakes because of not being able to select the proper parameters.

Comprehensive studies in this field together with on-board implementation were made since 1986 in the Institute of Heavy Machinery Engineering of Warsaw University of Technology. The research works carried by the team led by Prof. Jan Szlagowski, were focused on searching the complex solutions, which would allow for application the same methods in automation of different types of machines.

The first solution was the system WORM [1, 2] (Machine Operator Assistant System), implemented in excavator K-611 Waryński in 1990. The main functions of WORM are:

1. Position and load monitoring of working equipment.

2. Diagnostics.

3. Diesel engine control.

4. Measurement and acquisition of operating parameters.

Machine operator communicated with the system by an interface. The operator's console formed an LED touch screen with function keys together with the monitor screens on which the informations provided by the system were displayed. The works have been continued in the following directions:

1. Advanced digital control of excavator operation and automation of the whole operating cycle [3, 4, 5, 6, and 7].

2. Optimization of machinery working process $[4,5]$.

3. Studies on soil excavation processes.

4. Planning and optimization of machinery working movements sequences.

5. Implementation of new hardware and software solutions for excavator working process control (remote control, multiprocessor operation mechanisms, CAN network) [3].

6. Development of dynamic modeling methods [13].

7. Experimental tests on real excavator. The laboratory in Institute of Heavy Machinery Engineering of Warsaw University of Technology is equipped with a stand with automated excavator K121 and soil container (providing all operational movements as well as body turn) and the two stands for digital control of linear and rotational movements $[6,7,10,12]$.

Further works are described in the dissertation [11].

In the Building Mechanization and Mineral Mining Research Institute (IMBiGS) in Warsaw Prof. E. Budny developed the methodology of operational ranges analysis, static properties and operational capacity of single bucket excavator cutting systems [17]. This methodology was applied in many other elaborates describing the kinematics of excavator working equipment. Presumed by IMBiGS scheme of working equipment description for single bucket excavator was applied by many other scientific centers. In the IMBiGS there was also developed the method of determining the hodograph for soil loosening potential forces [16]. Current works in the Building Mechanization and Mineral Mining Research Institute are focused on optimization of excavator bucket trajectory. The process of soil loosening is examined from working equipment kinematics side, where cutting edge should follow the shortest path $[14,15,18]$. The free degrees of freedom are considered in searching for optimum trajectory: two linear coordinates of bucket cutting edge and bucket rotation. It is also assumed that the all three cylinders for working equipment are operated by three independent circuits of hydraulic system and dynamic effects connected with the process influence the optimum trajectory of the working equipment.

Investigations on tool movement control optimization are also conducted in Military University of Technology (WAT) in Warsaw. In the Institute of Building Machines there was developed and constructed the equipment position monitoring and control system utilizing laser analogue systems, that enables soil cutting by layers with programmable thickness, resulting in high accuracy of excavation outline [24]. Further works concerned the problems of remote control of excavators and military vehicles $[31,32]$ as well as vision systems for such machinery.

In Kielce University of Technology, the team led by Prof. W. Tr ${ }^{1}$ mpczynski built the unique in Poland as well as in Europe laboratory for research of soil cutting processes and movement control of excavators and loaders working equipment [22]. Various control algorithms were analyzed (methods: PTP, CPC, Teach etc.). Results are summarized in L. $\mathrm{P}^{3}$ onecki's qualifying dissertation [23].

A considerable high achievement among the Polish scientific centers in the field of soil cutting process optimization has the research team led by Prof. W. Trąmpczyński. Their works are related to energetic verification of soil shoving processes. As an optimization criterion the minimization of soil shoving resistance was assumed. Criterion fulfillment was achieved as a result of finding the 
soil discontinuity lines created during working tool movement [19, 20, 21]. The automated control system, which utilizes signals from soil resistance measurement system, was developed for tool guidance along the slip lines. Experiment results indicate that the trajectory generated automatically is energetically about $40 \%$ more efficient than trajectories obtained with manual control by a machine operator [21].

\section{Dynamic modeling of heavy machinery}

One of the methods of identification the dynamic problems accompanying automated machinery operation is computer simulation of its operation. In spite of many presumed idealizations, the computerized machinery model enables representation of basic energetic and informationrelated phenomena arising in the machine.

The main purpose of simulative experiments carried out on such idealized model is testing and estimating the influence of selected machinery parameters on its working process course. These advantages encourage many scientific centers to formulate computer models of machinery and to carry out experimental tests concerning model identification. The centers engaged in problems of modeling and testing the excavators are: Military University of Technology - Prof. S. Konopka's team [33], and Kielce University of Technology Prof. Gierulski's team. Furthermore, the investigations on hydrostatic drive systems modeling are carried out in Cracow University of Technology, under Prof. A. Garbacik management [29, 30]. Prof. W. Grzesikiewicz from Warsaw University of Technology formulated complex mathematical model of an excavator [13].

Presented model consists of mathematical relations between coordinates, used for description of energetic processes arising during excavator operation. Basing on this, the numerical methods of finding solution to the formulated mathematical problems together with a computer program for simulation of machinery working process were developed.

The team lead by Prof. J. Tomczyk from Technical University of Lodz for many years have been conducting research on dynamics of cranes. Complex dynamic models of overhead travelling cranes and harbor jib cranes [25, 26, 27]. Their works on formulation methodology of dynamic models of hydrostatic systems are presented in dissertation [28]. Prof. M. Trombski with his crew from Technical University of Łódz, and Prof. L. Tomski with his crew from Technical University of Czêstochowa formulated complex dynamic models of self-driven cranes.

\section{Algorithms for heavy machinery control}

Properly prepared algorithms are essential for automation of machinery working process. To reach the goal it is necessary to collect complete knowledge databases regarding the analyzed problems (functional models).

Prof. J. Szlagowski with his research team prepared and applied complex algorithms for hydraulic excavator and piling machine automated operation control. The methodology was described in dissertation [11].

Prof. J. Tomczyk with his crew prepared similar algorithms for overhead travelling cranes and harbor jib cranes operation control. The consideration was given to load positioning with oscillation dumping and wind disturbance compensation. The algorithms were verified experimentally [25, 26].

Dr. F. Kuczmarski from Military University of Technology carried similar works. The results are summarized in qualifying dissertation [34].

Dr. H. Dobrowolski from Warsaw University of Technology elaborated complex computer systems for excavator working process control [3]. Furthermore, the algorithm for excavator operation control with fuzzy logic controller was prepared $[4,5]$.

\section{Communication man - machine}

Communication between a man and a control system is a problem of particular importance, from both ergonomic and applied technology points of view. In case of construction machinery we may have an on-board communication system or remote communication - from dispatch center or via a mobile remote unit. Communication range depends on a level of machinery automation.

Assuming that the machinery operator is in fact a master decision system, communication with machinery should provide suitable level of feedback to facilitate decisions. Such feedback is realized by human senses, so it is possible to use visual, acoustic (including voice) and mechanical (touch) stimulus. Visual information is of greatest importance as the reaction on it is fastest and most comprehensive. Acoustic signals have definitely lower meaning and could be treated as a supplementary information (alarm). Voice navigation is a future - apparently not so farmatter.

The contents and form of the information supplied to operator is extremely important. The system should not communicate all the data gathered. So it is necessary to select the data, with respect to the following two criteria:

- activity context, i.e. transmitting only these information that may have direct influence on currently realized processes, information weight (importance); 
- $\quad$ system must be able to decide which information are important, and which are irrelevant in particular situation, while the machinery operator at any time can demand information of any kind stored by the system.

Such communication systems were developed in Institute of Heavy Machinery Engineering of Warsaw University of Technology, basing on screen windows concept. The two application were made: on hydraulic excavator and on piling machine [3, 8]. The graphic presentation will be shown during the Congress.

\section{Examples of applications}

Because of transformation of Polish economy, construction machinery market in our country is in difficult situation now. The only one significant manufacturer is Stalowa Wola. Therefore only some of research work results were utilized by industry. The two of them will be discussed here.

Prof. J. Tomczyk together with his crew and Detrans company has prepared automated overhead travelling crane, and carries works on automation of harbor jib crane, too. The overhead travelling crane makes precise cargo positioning with optimization of load travel. For more precise operation, the cargo oscillation dumping system enables was introduced. The team has ready-to-use industrial solutions [27].

The other example is automated piling machine PG20. "Legmet" S.A. from Legnica produced a prototype of piling machine PG 20. Basic machine for the PG 20 is the special version of an excavator BRAWAL 1611. Piling machine PG 20 is designed to make piles of max. diameter $1800 \mathrm{~mm}$ without tube system and of max. diameter $1500 \mathrm{~mm}$ with tube system. It is equipped with the mechanism allowing for making vertical and inclined piles.

The Institute of Heavy Machinery Engineering of Warsaw University of Technology in cooperation with Roads and Bridges Research Institute designed and produced an on-board computer system with operator interface, allowing for automation of certain machine preparation works as well as measurement and acquisition of selected operating parameters. Recorded data are used for creating reports on piles made, thus simplifying work acceptance procedures. The manufacturer and machine users requested meeting the following requirements:

- automation of column positioning at a given angle to gravitational level in X-Z plane (related to the longitudinal axis of machine body) within the range of $(-15 \div 20 \mathrm{deg})$ from vertical line;

- generation of reports concerning pile making (in the form of file capable to be transmitted to external system);
- monitoring of selected parameters represented in digital or graphic form on the machine operator terminal;

- selected parameter data acquisition for research purposes (in the form of file capable to be transmitted to external system).

Communication with operator is realized via LCD display equipped with a touch panel. The display is connected with system cassette through serial port RS232. It enables an interactive data input and output as well as option selection. Data are presented on the screen both in graphical and numerical way.

The other examples will be shown during presentation of this paper.

\section{Bibliography}

1. Dąbrowski D., Dobrowolski H., Poncyliusz M., Szlagowski J.: Koparka 611 Waryński z układami automatyzujacymi pracę. Przegląd Mechaniczny, Zeszyt 10/95.

2. Dąbrowski D., Dobrowolski H., Poncyliusz M., Selenta A., Szlagowski J., The communication within heavy machine operator assistant system (HMOAS),Procc. of $11^{\text {th }}$ Int. Symp. on Automation and Robotics in Construction, Brighton 1994.

3. Dobrowolski H. On-board computer system for an excavator Proc. of ISARC (Int. Symposium on Automation and Robotics in Construction) XII, Warszawa 1995, vol.I pp.143-149

4. Sza $^{3}$ ek A., Szlagowki J.: Fuzzy logic applied to optimise the work performance of hydraulic backhoe excavator, The Second International Conference on Soft and Intelligent Computing, Budapest 1999.

5. $\mathrm{Sza}^{3} \mathrm{ek}$ A.: Optimisation of excavator backhoe functional motion using fuzzy logic controller, PhD thesis, Warsaw 2001T.

6. Miros ${ }^{3}$ aw T, Szlagowski J., ebrowski Z., "Position control-algoruthm of hydraulicdrive of working machine"2-nd International Scientific Forum "Developments in Fluid Power Control of Machinery and Manipulators" Cracow, Poland 28.062.07.2000.

7. Mirosªw T, Szlagowski J., - ebrowski Z., "Control and position control-of rotary drive in the working machine" Drittes DeutschPolnisches Seminar "Innovation und Fortschritt in der Fluidtechnik";Zakopane, Polen 16-17 September 1999.

1. Szlagowski J., Dąbrowski D., Dobrowolski, System komputera pokładowego dla palownicy PG-20 ,Przegląd Mechaniczny,9,1998,str 9-11.

9. Szlagowski J., Dąbrowski D., Dobrowolski, Badanie maszyn z systemami monitorowania położenia narzędzia roboczego,Maszbud 1996,18-1 -18-4. 
10. Szlagowski J., Dąbrowski D., Dobrowolski, New concept of computer system for heavy machines, Developments in fluid power control of machinery and manipulators, $2^{\text {nd }}$ Int.Scientific Forum, Kraków,July 2000,pp6769.

11. Problemy automatyzacji pracy maszyn roboczych, Praca zbiorowa pod redakcja J.Szlagowskiego, Wyd MET, Warszawa 2001.

12. Szlagowski J., Dąbrowski D., Godala M.: Experimental laboratory computer system for hydraulic systems control, $2^{\text {nd }}$ Int. Scientific Forum, Kraków, July 2000,pp164-167.

13. Grzesikiewicz W.: "Dynamics of mechanical systems with constraints" (In Polish). Prace Naukowe Politechniki Warszawskiej, Mechanika z.117. WPW, Warszawa 1990.

14. Budny E., and Gutkowski W., Kinematically induced excavation by backhoe excavator, 13 th ISARC, Proceedings, 1996, pp 673-680

1. Gutkowski W., Chłosta M., Sensitivity of the Bucket Motion in Controlled Excavation, ANC 8 th Int. Topical Meeting on Robotics and Remote Systems, April 25-29, 1999, Pittsburgh

16. Dudczak A., "Kryteria doboru parametrów mechanizmów napędowych osprzętu koparki hydraulicznej." Prace IMB Warszawa 1977r.

17. Budny E., "Podstawy racjonalnego projektowania wieloczłonowych układów maszyn roboczych na przykładzie koparek hydraulicznych.” Prace naukowe Mechanika z.148, Wydawnictwo P.W. Warszawa 1993r.

18. Budny E., Chłosta M., Gutkowski W., "Optymalna droga łyżki koparki." Materiały XII Konferencji Naukowej PRMR Zakopane 1999r.

19. Trąmpczyński W., “Automatyzacja mechanicznego urabiania gruntów narzędziami maszyn budowlanych.” IPPT PAN, Warszawa 1996r.

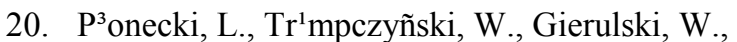
Cendrowicz, J., Soko³owski, K., "Computer control system for heavy machine fixtures motion and its application for automatic generation of cutting tool trajectories according to the given criteria", Engineering Transaction, $48 / 2000$.

21. Jarzêbowski, A., Maciejewski, J., Szyba, D., $\operatorname{Tr}^{1}$ mpczyñski, W., "On the energetically most efficient trajectories for heavy machine shoving process", Engineering Transaction, Vol. 43, 12, 1995.

22. $\mathrm{P}^{3}$ onecki, L., $\operatorname{Tr}^{1}$ mpczyñski, W., Cendrowicz, J., "A concept of digital control system to assist the operator of hydraulic excavators", Automation in Construction, Elsevier, 7/1998.

23. $\mathrm{P}^{3}$ onecki, L., " The computer control of the fixture of machines for earthworks on example of the single-bucket hydraulic excavator" (in
Polish), Reports of Technical University of Kielce, 16/1999.

1. Krasuski, Kuczmarski F., Typiak A., "Zastosowanie detektora analogowego śledzącego położenie osprzętu roboczego w układzie kontroli głębokości kopania koparki jednonaczyniowej.” Materiały XII Konferencji Naukowej PRMR Zakopane 1999r.

25. Cink J., Tomczyk J.: “Kompensacja zakłóceń działaniem wiatru w ruchu roboczym żurawia portowego". V Konferencja Okrętownictwo i Oceanotechnika - Maszyny i Systemy Transportowe,. Szczecin - Międzyzdroje, czerwiec 2000, (s. 31-42).

26. Cink J., Tomczyk J.: “Zakłócenia spowodowane działaniem wiatru $\mathrm{w}$ automatycznym sterowaniu maszyn roboczych". Problemy Maszyn Roboczych, Zeszyt 13, 1999, (s. 93-101).

27. Tomczyk J. i inni: "Eliminacja wahań ładunku i pozycjonowanie dźwignic o ruchach obrotowych i wypadowych sterowanych za pomocą mikroprocesorów". Prace dla Komitetu Badań Naukowych. Łódź, 1999.

28. Tomczyk J.: "Modele dynamiczne elementów i układów napędów hydrostatycznych". WNT, Warszawa 1999.

29. Garbacik A., K. Szewczyk K, "New aspects of modeling of fluid power control", WrocławWarszawa-Kraków, Ossolineum 1995.

30. Andrzej Garbacik \& Jacek Stecki : "Developments in fluid power control of machinery". Cracow 2000.

31. S. Konopka, F. Kuczmarski, A. Typiak, "Sterowanie pojazdów i maszyn inżynieryjnych w układzie teleoperatora", XII Konferencja Naukowa, Napęd, sterowanie, automatyzacja maszyn roboczych i pojazdów, WAT. Rynia k/Warszawy 2000.

32. S. Konopka, F. Kuczmarski, J. Wrona, "The concept of remote controlled heavy mine clearance vehicle", Fall 2000 Panel Business Week and Symposium on "Unmanned vehicles (UV) for aerial, ground and naval military operations", Ankara, Turkey 2000.

33. Borkowski w., Konopka s., Prochowski 1.: "Dynamika maszyn roboczych", WNT, Warszawa 1996. 